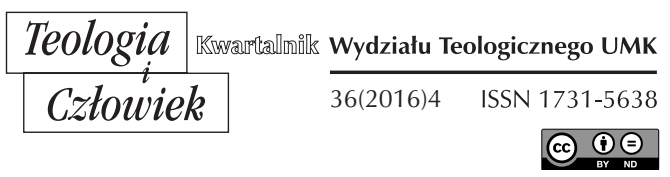

BEATA BILICKA*

TORUŃ

\title{
ROZBUDZIĆ PAMIĘĆ CHRZTU. \\ (KATECHEZA O CHRZCIE ŚW. Z WYKORZYSTANIEM EPORTFOLIO)
}

DOI: http://dx.doi.org/10.12775/TiCz.2016.041

Obchody 1050 rocznicy chrztu Polski, przypadające w 2016 roku, kierują uwagę nie tylko w stronę wydarzenia, które przed wiekami radykalnie wpłynęło na losy polskiego narodu i Kościoła, lecz także na sakrament chrztu świętego - wydarzenia całkowicie zmieniające duchowe życie ochrzczonego. Okres niemowlęctwa, w którym najczęściej w Polsce przyjmuje się chrzest święty, powoduje, że często zapomina się o tym dniu, nie pamięta jego daty. Dlatego potrzeba działań duszpasterskich i katechetycznych mających na celu rozbudzenie wśród wiernych pamięć dnia zrodzenia do życia nadprzyrodzonego.

Celem niniejszego artykułu, z konieczności ograniczonego do kilku stron wymaganiami wydawcy, będzie opisanie możliwości zastosowania metody ePortfolio w szkolnym nauczaniu religii, w celu rozbudzenia pamięci chrztu, o którą nieraz prosił papież Franciszek. Nauczanie papieskie, jak zauważył Wojciech Osial, zasługuje na szczególną uwagę co najmniej z dwóch powodów. Jest to nauczanie Piotra naszych czasów, „który kie-

* Beata Bilicka - doktor habilitowana nauk teologicznych w zakresie katechetyki. Od 2001 r. adiunkt na Wydziale Teologicznym UMK w Toruniu. 
ruje Kościołem i wyznacza kierunki jego misji” oraz jest to nauczanie, w którym Ojciec Święty „porusza kilka kwestii, które jakkolwiek mogą być już znane, to jednak pozostają wciąż ważne dla ewangelizacyjnej odnowy dzisiejszej katechezy" ${ }^{1}$. Do tego należy dodać, że papież posługuje się charakterystycznym dla siebie „językiem bliskości”, który - zdaniem biskupa Marcello Semeraro - powinien być wzorcem dla języka nowej ewangelizacji ${ }^{2}$, potrzebnej również w polskiej szkole.

Nauczanie papieża Franciszka jest bez wątpienia dla nauczycieli religii cenną wskazówką i drogowskazem, którymi powinni kierować się w pracy katechetycznej. To kryterium wyznacza strukturę niniejszego artykułu, który składa się z trzech części. W pierwszej krótko zostaną scharakteryzowane istotne elementy papieskiej katechezy o chrzcie; to w niej odnajdujemy sugestię, aby rozbudzić wśród wiernych pamięć tego sakramentu. Następnie, w drugiej części, zostaną przedstawione narzędzia niezbędne do tworzenia ePortfolio. W ostatnim punkcie opiszemy zastosowanie metody ePortfolio w szkolnym nauczaniu religii w celu rozbudzenia wśród młodzieży gimnazjalnej pamięci chrztu św. Całość wieńczyć będzie krótkie zakończenie.

Podstawowym źródłem naszego opracowania będą przede wszystkim dwie katechezy środowe na temat chrztu świętego, wygłoszone przez papieża Franciszka w cyklu siedmiu katechez o sakramentach.

\section{POTRZEBA ROZBUDZENIA PAMIĘCl CHRZTU W KATECHEZACH ŚRODOWYCH PAPIEŻA FRANCISZKA}

Katechezy papieża Franciszka głoszone podczas środowych audiencji generalnych są kontynuacją dzieła Benedykta XVI. W pierwszym roku swojej piotrowej posługi, papież dokończył cykl katechez rozpoczęty przez poprzednika, podczas pierwszej katechezy wygłoszonej 27 marca 2013 r. powiedział: „Z wielką wdzięcznością i czcią podejmuję świadectwo z rąk mego umiłowanego poprzednika, Benedykta XVI. Po Wielkanocy

1 W. Osial, Wizja wspótczesnej katechezy w nauczaniu papieża Franciszka, „Warszawskie Studia Teologiczne" 27 (2014)1, s. 293.

2 Por. M. Semeraro, Wprowadzenie do adhortacji apostolskiej „Evangelii gaudium”, tłum. K. Stopa, Częstochowa 2014, s. 9. 
podejmiemy na nowo katechezy Roku Wiary”. Następny cykl katechez, głoszonych od 8 stycznia do 2 kwietnia 2014 roku, poświęcony był sakramentom świętym. Kolejne cykle dotyczyły Ducha Świętego (9 IV - 11 VI 2014 r.), Kościoła (18 VI - 26 XI 2014 r.), rodziny (10 XII 2014 r. - 16 IX 2015 r.), miłosierdzia (od 13 I 2016 r.).

W katechezach dotyczących chrztu świętego, wygłoszonych 8 i 15 stycznia 2014 r., papież zwrócił uwagę przede wszystkim na dwie kwestie: doniosłość dnia chrztu oraz łączność ochrzczonego z Chrystusem i Ludem Bożym. Wcześniej, podczas środowej audiencji generalnej 13 listopada 2013 r. omówił, w ramach rozważań na temat Credo, związek chrztu z sakramentem pokuty. Swoją refleksję podzielił na trzy części: „wyznaję”, „jeden chrzest” i „na odpuszczenie grzechów”. W pierwszej podkreślił, że „Chrzest jest w pewnym sensie dowodem osobistym chrześcijanina, metryką urodzenia. Jest to metryka zrodzenia w Kościele”3, jest jakby dniem drugich narodzin - pierwszy był dniem zrodzenia do życia, drugi dniem zrodzenia dla Kościoła. Zauważył, że często zapominamy o tym drugim dniu, mimo że co roku świętujemy urodziny. Z chrztem związana jest nasza wiara w odpuszczenie grzechów. Chrzest jest początkiem drogi nawrócenia człowieka ku Bogu, „która trwa całe życie i która jest nieustannie wspierana przez sakrament pokuty" ${ }^{4}$. W charakterystyczny dla siebie, obrazowy, sposób Franciszek wyjaśnił, że „spowiedź nie jest posiedzeniem $w$ jakiejś sali tortur - jest świętem, obchodzeniem dnia na-

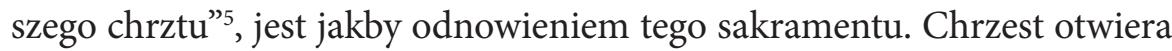
drzwi do Kościoła, a spowiedź - ze względu na nasze słabości - otwiera je na nowo. W drugiej części katechezy na temat Credo, papież wyjaśnił etymologię słowa chrzest, które oznacza duchowe „zanurzenie” w śmierci Chrystusa, z której wskrzeszeni jesteśmy jako nowe stworzenie. Zwrócił uwagę na odradzające i oświecające obmycie. „Chrzest oświeca nas wewnętrznie światłem Jezusa”, zwłaszcza tych, „którzy są w ciemnościach i nie dostrzegają żadnych przebłysków jasności na horyzoncie swego

${ }^{3}$ Franciszek, Chrzest na odpuszczenie grzechów. Katecheza papieża Franciszka z 13 listopada 2013 r., http://papiez.wiara.pl/doc/1777993.Chrzest-na-odpuszczenie-grzechow (dostęp: 16.08.2106).

4 Tamże.

5 Tamże. 
życia"'. Daje nam moc i światło pochodzące od Chrystusa. Chrzest nie jest wyłącznie wydarzeniem z przeszłości, ale rzeczywistością, która dotyczy teraźniejszości. W ostatniej części katechezy papież podkreślił, że chrzest jest „potężną Interwencją Bożego Miłosierdzia w naszym życiu”, odpuszcza nam wszystkie grzechy, ale nie pozbawia ludzkiej natury słabości, dlatego musimy odnawiać łaskę chrzcielną w sakramencie pokuty. Chrzest możemy otrzymać tylko raz w życiu, ale w sakramencie spowiedzi za każdym razem się on odnawia ${ }^{7}$.

8 stycznia 2014 r., od rozważań na temat sakramentu chrztu, papież Franciszek rozpoczął cykl katechez o sakramentach św. Na początku przypomniał, że chrzest wraz z Eucharystią i bierzmowaniem należy do sakramentów wtajemniczenia chrześcijańskiego. Nie jest tylko zwykłą formalnością, ale aktem dogłębnie dotykającym naszą egzystencję.

Nie jest tym samym dziecko ochrzczone i nie ochrzczone, osoba ochrzczona i nie ochrzczona. Poprzez chrzest jesteśmy zanurzeni w tym niewyczerpanym źródle życia, jakim jest śmierć Jezusa, będąca największym aktem miłości w całej historii. Dzięki tej miłości możemy żyć nowym życiem, nie we władzy zła, grzechu i śmierci, ale w komunii z Bogiem i z braćmi! .

Mimo że jest to bardzo ważny dzień w życiu, ochrzczeni często nie pamiętają jego daty. Przyczyną tego jest między inny fakt, że najczęściej chrzest przyjmuje się wkrótce po urodzeniu, co jednakże nie powinno być żadnym usprawiedliwieniem. Papież mocno podkreśla, aby znać datę, kiedy zostało się zanurzonym w Jezusowym nurcie zbawienia. „Jeśli nie będziemy jej znali, grozi nam zatracenie pamięci tego, co Pan w nas uczynił, pamięci o otrzymanym przez nas darze. Wtedy ostatecznie uważamy go za pewne wydarzenie, które odbyło się w przeszłości - i nie z powodu naszej woli, ale woli naszych rodziców. Dlatego też nie ma on żadnego wpływu na teraźniejszość"’" Chrzest jest rzeczywistością aktualną, a nie tylko jednorazowym wydarzeniem z odległej przeszłości, dlatego Franci-

6 Tamże.

7 Por. tamże.

${ }^{8}$ Franciszek, To jest dzień święta. Katecheza papieża Franciszka z 8 stycznia 2014 r., http://papiez.wiara.pl/doc/1841479.To-jest-dzien-swieta (dostęp: 16.08.2106).

9 Tamże. 
szek apeluje, aby „rozbudzić pamięć naszego chrztu”, by żyć nim każdego dnia. Zwraca uwagę na jeszcze jeden ważny aspekt tego sakramentu nasze wszczepienie „w relację Jezusa $\mathrm{z}$ Bogiem Ojcem; niesiemy nową nadzieją, bo chrzest daje nam ową nową nadzieję, nadzieję podążania drogą zbawienia przez całe życie, a tej nadziei nic i nikt nie może zgasić, bo nadzieja nie zawodzi"10.

Głosząc katechezy o chrzcie świętym, papież nie zapomniał także o ubogich. Charakterystyczna dla obecnego pontyfikatu Franciszkowa opcja na rzecz ubogich ma także w tym miejscu uzasadnienie chrystologiczne: „Dzięki sakramentowi chrztu św. jesteśmy w stanie przebaczać i kochać nawet tych, którzy nas obrażają i czynią nam zło; udaje się nam rozpoznać w ostatnich i ubogich oblicze Pana, który nas nawiedza i staje się bliskim. Chrzest pomaga nam rozpoznać w obliczu osób potrzebujących, cierpiących, także $\mathrm{w}$ naszym bliźnim oblicze Jezusa, dzięki tej mocy chrztu"11. Sakrament ten, zdaniem papieża, jest aktem braterstwa i usynowienia w Kościele. Podkreśla to jego celebracja, widać w niej matczyny wymiar Kościoła, który stale rodzi nowe dzieci w Chrystusie i w „owocności Ducha Świętego”. Katechezę papież zakończył apelem, aby znać datę chrztu, tak jak się zna datę swoich urodzin ${ }^{12}$.

Papież Franciszek naucza prostym i przystępnym językiem, nie pozbawionym jednakże wymiaru teologicznego. W swoich katechezach odwołuje się do Pisma Świętego, Magisterium Kościoła, pisarzy i Ojców Kościoła. W katechezie o chrzcie św. wygłoszonej 15 stycznia 2014 r., powołując się na św. Tomasza z Akwinu oraz - jak sam nazwał - „szkołę" Soboru Watykańskiego II, podkreślił znaczenie eklezjalnych skutków sakramentu, który czyni ochrzczonego członkiem Ciała Chrystusa i wprowadza do Ludu Bożego, „Ludu w drodze, pielgrzymującego w dziejach”"13. Stosując porównanie do łańcucha przekazywania życia z pokolenia na pokolenie, papież zauważył, że przekazywanie łaski Bożej, począwszy od nakazu Jezusa, aby głosić Ewangelię i chrzcić, również dokonuje się

10 Tamże.

11 Tamże.

12 Por. tamże.

${ }^{13}$ Franciszek, Chrzest czyni członkami Kościoła. Katecheza papieża Franciszka z 15 stycznia 2014 r., http://papiez.wiara.pl/doc/1851823.Chrzest-czyni-czlonkami-Ciala-i-Ludu (dostęp: 16.08.2106). 
w swoistym łańcuchu „przekazywania wiary, z powodu chrztu. Każdy z nas jest ogniwem tego łańcucha, nieustannie krokiem naprzód, jak nawadniająca rzeka"14. Nie możemy bowiem, jak podkreśla Franciszek, sami się zbawić. Konieczna jest wspólnota, w której otrzymuje się chrzest i która powinna stać się dla ochrzczonego integralną częścią jego chrześcijańskiego życia, a nie jakąśs „otoczką” lub „dodatkiem”. Wymiar wspólnotowy jest bardzo ważny, ponieważ wiara chrześcijańska rodzi się i żyje w Kościele. Chrześcijanie jako wspólnota nie tylko doświadczają Bożej miłości, lecz także mają powinność dzielenia się tym doświadczeniem z innymi, bycia „kanałami łaski jedni dla drugich, pomimo naszych ograniczeń i naszych grzechów”15. Obowiązek niesienia światu Ewangelii jest konsekwencją przyjęcia chrztu św., który czyni ochrzczonego zarazem uczniem otrzymującym wiarę i misjonarzem przekazującym wiarę. Każdy chrzczony, nawet najmniejszy, jest misjonarzem i każdy, który wydaje się największym, jest uczniem. Także biskupi i papież, „bo gdyby nie byli uczniami, to nie mogliby czynić dobra, nie mogliby być misjonarzami, przekazywać wiarę"16. Chrzest nie jest wydarzeniem z przeszłości, ale przede wszystkim wydarzeniem, które jest zaproszeniem do misyjnej posługi nie tylko we wspólnocie Ludu Bożego, ale również wobec każdego potrzebującego, którego chrześcijanin spotka w miejscu, wyznaczonym mu przez Pana ${ }^{17}$.

\section{CHARAKTERYSTYKA METODY EPORTFOLIO}

Portfolio $^{18}$ to sposób dokumentowania pracy np. artysty, wykorzystywany między innymi jako uzupełnienie curriculum vite, chociaż - co należy podkreślić - portfolio nie jest kwestionariuszem osobowym. Tradycyjne portfolio przygotowywane jest często $\mathrm{w}$ formie papierowej

14 Tamże.

15 Tamże.

16 Tamże.

17 Por. tamże.

${ }^{18} \mathrm{~W}$ tej części korzystam z niektórych przeredagowanych i zaktualizowanych fragmentów mojego artykułu ePortfolio $i$ WebQuest w szkolnym nauczaniu religii, w: Katecheta i katechizowany w Sieci, red. B. Bilicka, Torun 2015, s. 87-111. 
teczki lub segregatora i może mieć zastosowanie także w edukacji, np. do regularnego gromadzenie prac uczniów (sprawdzianów, kartkówek itp. $)^{19}$, nosi wówczas nazwę portfolia edukacyjnego i wykorzystywane jest $\mathrm{w}$ procesie oceniania. Takie portfolio może być jednak postrzegane przez młodzież zafascynowaną technologią informacyjno-komunikacyjną, jako metoda archaiczna, dlatego warto je zastąpić ePortfolio ${ }^{20}$, do wykonania którego potrzebny jest dowolny edytor tekstu oraz dostęp do Internetu.

W Sieci odnaleźć można wiele artykułów na temat ePortfolio ${ }^{21}$, dostępny jest również bezpłatny Międzynarodowy Magazyn ePortfolio (International Journal of ePortfolio) - półrocznik wydawany przez Uniwersytet Stanowy Wirginii ${ }^{22}$ oraz Podręcznik wdrażania ePortolio ${ }^{23}$. Cenne wskazówki na temat wykorzystania ePortfolio w edukacji publikuje na swojej stronie internetowej Lechosław Hojnacki ${ }^{24}$, do którego będziemy odwoływać się w naszych rozważaniach.

Wspomniany autor wskazuje, że „ePortfolio jest powszechnie rozumiane jako tworzona przez właściciela kolekcja cyfrowych obiektów demonstrujących doświadczenia, osiągnięcia i dowody związane z umiejętnościami i kompetencjami lub (w przypadku uczniów) także z procesem uczenia się. Tak wąsko rozumiane ePortfolio, to produkt, przekrój czasowy, wyciąg stworzony w konkretnym momencie, w konkretnym zastosowaniu, dla konkretnego odbiorcy. Taki przekrój ePortfolio w naszej

19 Własne portfolia przygotowują także nauczyciele ubiegający się o stopień awansu zawodowego, zwłaszcza nauczyciela dyplomowanego.

${ }^{20}$ Nie ma jednej reguły określającej sposób pisowni ePortfolio. W Internecie odnaleźć można: e-Portfolio, e-portfolio, ePortfolio. W naszym artykule przyjmujemy za L. Hojnackim pisownię ePortfolio.

${ }^{21}$ Przykładowe ePortfolio Helen Barrett znajdują się na stronie: https://docs. google.com/presentation/d/13WzjPnvO1nRZGKE1qifCfLh8GKQk0x1_KYL3LLD5_5Y/ present\#slide=id.i0 (dostęp: 12.08.2016). Dr Helen Barrett jest emerytowanym pedagogiem, znaną w USA i Europie propagatorką ePortfolio. Prowadzi badania m.in. na temat wpływu elektronicznych portfolio na procesy uczenia się, motywację i zaangażowanie uczniów. Autorka licznych książek i artykułów; od 1991 r. publikuje na stronie: http:// electronicportfolios.org/ (dostęp: 25.07.2016).

${ }_{22}$ Zob. http://www.theijep.com/ (dostęp: 25.07.2016).

${ }^{23}$ Zob. http://www.enauczanie.com/eportfolio/podrecznik (dostęp: 25.07.2016).

${ }^{24} \mathrm{http}: / /$ www.enauczanie.com/start (dostęp: 25.07.2016). 
metodzie nosi nazwę „ePortfolio prezentacyjnego"25. Ważnym elementem ePortfolio jest sam proces jego tworzenia, dlatego Lechosław Hojnacki przestrzega przed błędnym rozumieniem ePortfolio wyłącznie w kategoriach finalnego produktu, a nie procesu. Jego zdaniem takie ePortfolio nie ma głębszego sensu edukacyjnego, musi bowiem obejmować dwie fazy: zarówno proces wdrażania, który jest kilkuetapowy, jak i ciągły cykl pracy na już wdrożonym ePortfolio ${ }^{26}$.

Nauczyciel religii ma do dyspozycji wiele narzędzi do tworzenia ePortfolio. Wielość tych narzędzi, ich dostępność i różne stopnie trudności pozwalają na właściwy - ze względu na stopień opanowania zarówno przez ucznia, jak i nauczyciela - wybór i zastosowanie. L. Hojnacki dzieli na je dziesięć kategorii ${ }^{27}$, poniżej omówimy tylko wybrane.

\subsection{EPORTFOLIO NA STATYCZNYCH STRONACH INTERNETOWYCH}

Statyczne strony internetowe budowane są na kodzie HTML. Tworzenie takiej strony można zlecić firmie zajmującej się komercyjnym projektowaniem; jest to usługa płatna, także w przypadku każdej zmiany na stronie, dlatego zalecana tym, którzy nie potrzebują częstej aktualizacji danych na stronie. W sytuacji, kiedy nauczyciel nie potrafi lub nie chce tworzyć własnej strony WWW lub bloga, ePortfolio na statycznych stronach internetowych może pełnić funkcję jego „osobistej wizytówki” w Sieci. W praktyce szkolnej ePortfolia na statycznych stronach internetowych nie mają zastosowania i uzasadnienia, ponieważ posiadają wiele wad: wymagają hostingu; niełatwa jest ich organizacja, publikacja, korekta, aktualizacja; nie posiadają także mechanizmów wspomagania (np. wyszukiwania i kategoryzacji ${ }^{28}$.

${ }^{25} \mathrm{http} / / /$ www.enauczanie.com/eportfolio/metoda (dostęp: 12.08.2016).

${ }^{26}$ Por. http://www.enauczanie.com/eportfolio/metoda/etapy (dostęp: 12.08.2016).

27 Zob. http://www.enauczanie.com/eportfolio (dostęp: 12.08.2016).

${ }_{28}$ Por. http://www.enauczanie.com/eportfolio/narzedzia/statyczne (dostęp: 12.08.2016) 


\subsection{EPORTFOLIO ZA POMOCĄ NARZĘDZI DO TWORZENIA PREZENTACJI}

Do tworzenia tego typu ePortfolio używa się takich samych narzędzi, jak do przygotowania zwykłej prezentacji; L. Hojnacki dzieli je na trzy grupy: „PowerPoint (i podobne) - popularne narzędzie offline; Prezentacje Google Docs (i podobne) - narzędzia umożliwiające tworzenie prezentacji online i interakcje $\mathrm{z}$ PowerPointem; Narzędzia online niestandardowe - nie współpracujące z PowerPointem (np. prezi.com)"29. Tego typu ePortfolia nie znajdują większego zastosowania w edukacji, aczkolwiek mogę pełnić funkcję ePortfolia prezentacyjnego, zwłaszcza wówczas, gdy nauczyciele i uczniowie nie mają dostępu do Internetu ${ }^{30}$.

\subsection{EPORTFOLIO ZA POMOCĄ MECHANIZMÓW BLOGOWYCH}

To stosunkowo łatwy sposób tworzenia ePortfolio za pomocą bezpłatnego i ogólnodostępnego serwisu online, jakim jest Google Blogger. Posiada zalety, między innymi: jest łatwy w obsłudze, bezpłatny, nie wymaga żadnej instalacji, posiada system tagów. Jego wady to brak hierarchii, gotowej struktury, sterowania uprawnieniami, repozytorium dowolnych plików $^{31}$. Google Blogger jest dostępny dla każdego i nie wymaga od użytkownika specjalistycznej wiedzy oraz umiejętności informatycznych.

\subsection{EPORTFOLIO W GOOGLE SITES}

Google Sites (czyli Witryny Google) ${ }^{32}$ to internetowy, ogólnodostępny i bezpłatny edytor, który pozwala swoim użytkownikom względnie łatwo oraz szybko zbudować własną stronę internetową. Zestawienie zalet i wad Google Sites przygotowane przez L. Hojnackiego pokazuje, że jest

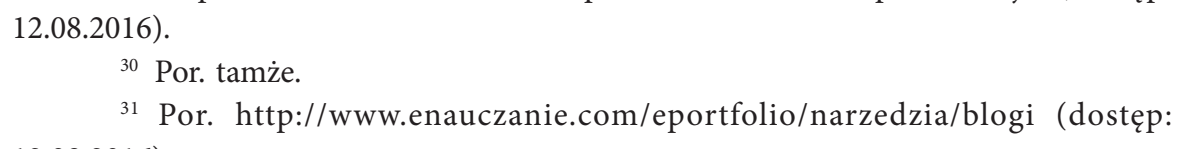

\footnotetext{
${ }^{30}$ Por. tamże.

31 Por. http://www.enauczanie.com/eportfolio/narzedzia/blogi (dostęp:
}

${ }^{29} \mathrm{http} / / /$ www.enauczanie.com/eportfolio/narzedzia/prezentacje (dostęp: 12.08.2016).

32 http://sites.google.com (dostęp: 12.08.2016). 
to dobre narzędzie, które może służyć nauczycielom w celu przygotowania ePortfolio. Jego zalety to:

- Dość łatwy start;

- Nowoczesny silnik: w pełni obsługiwany przez WWW;

- Bezterminowo bezpłatny i bez reklam;

- Łatwość tworzenia łatwej w nawigacji struktury hierarchicznej (drzewiastej);

- Powszechnie używany do ePortfolio;

- Wysoka estetyka - wiele szablonów do wyboru (oraz możliwość ich modyfikacji);

- Wysoka interoperacyjność - miejsce do przechowywania plików (oraz możliwość łatwego dołączenia przestrzeni Google Docs);

- Łatwość osadzania multimediów i dokumentów w dowolnym miejscu stron;

- Dostępny blogowy typ strony do wyboru (ogłoszeniowa);

- Może być łatwo duplikowana;

- Możliwość nadawania różnych uprawnień różnym stronom (Nowość! np. dostęp tylko po zalogowaniu) ${ }^{33}$.

Google Sites nie ma jednak gotowego schematu/układu ePortfolio, nie daje możliwości przeciągania plików do przeglądarki internetowej, a komentowanie jest możliwe jedynie po uzyskaniu uprawnień do danego konta, nie ma także systemu słów kluczowych ${ }^{34}$.

\subsection{EPORTFOLIO W SYSTEMIE MAHARA}

Mahara $^{35}$ to w pełni funkcjonalna aplikacja internetowa służąca do budowania ePortfolio, tworzenia dziennika, bloga; pozwala kontaktować się w Sieci, tworzyć społeczności internetowe, przesyłać pliki. Potrzebuje jednak instalacji na serwerze, można ją wykorzystywać między innymi na platformie zdalnego nauczania Moodle. System Mahara wymaga więc

${ }^{33}$ http://www.enauczanie.com/eportfolio/narzedzia/google-sites (dostęp: 12.08.2016).

${ }^{34}$ Por. tamże.

35 Zob. http://mahara.org/ (dostęp: 12.08.2016). Jest to macierzysty serwer systemu Mahara, który pozwala na założenie pięciogodzinnego konta demo, por. http://www. enauczanie.com/eportfolio/narzedzia/mahara (dostęp: 12.08.2016). 
hostingu oraz wiąże właściciela ePortfolio $\mathrm{z}$ instytucją, która dysponuje systemem i jest odpowiedzialna za profesjonalną obsługę serwera, jego konserwację itp. ${ }^{36}$. Mahara jest narzędziem do tworzenia środowiska nauki, rozwoju osobistego i kontaktów w Sieci. Jest bezpłatna, powszechnie dostępna, zbudowana na otwartych zasobach, tworzą ją entuzjaści na całym świecie, ma też swoich zwolenników w Polsce. W Internecie znaleźć można samouczek Mahary w języku polskim ${ }^{37}$. Członkowie społeczności Mahara spotykają się ze sobą także w realnym świecie, uczestniczą w licznych konferencjach i sympozjach ${ }^{38}$, udostępniają swoje prezentacje ${ }^{39}$, publikują książki. Największą na świecie społecznością użytkowników Mahara jest FolioSpaces. Jest to najpopularniejsza darmowa platforma służąca do budowania ePortfolio. Znajduje zastosowanie $\mathrm{w}$ edukacji, korzystają $\mathrm{z}$ niej studenci, nauczyciele i specjaliści różnych dziedzin ${ }^{40}$.

Możliwość tworzenia ePortfolio dają także sale przedmiotowe na Fronterze, który jest „profesjonalnym serwisem internetowym dla szkół, oferującym nauczycielom wartościowe narzędzia do pracy z uczniami”"41. Jest to łatwa w obsłudze platforma edukacyjna dla nauczycieli, która niestety nie podsiada sal do religii.

Spośród wymienionych narzędzi najłatwiejsze pod względem dostępu, jak i samego zastosowania (nie jest wymaga znajomość języka angielskiego), zarówno dla uczniów, jak i nauczycieli, są Google Blogger i Google Sites. Należą do usług Google, dlatego zanim będzie można ich używać do tworzenia blogów i stron internetowych, trzeba najpierw założyć darmowe konto Google.

${ }^{36}$ Por. http://www.enauczanie.com/eportfolio/narzedzia/mahara (dostęp: 12.08.2016).

37 Zob. http://wikieducator.org/Mahara_i_ePortfolio_-_samouczek (dostęp: 12.08.2016). Instrukcja instalacji Mahara $1.9 \mathrm{w}$ języku angielskim znajduje się na stronie: http://wiki.mahara.org/index.php/System_Administrator\%27s_Guide/Installing_Mahara (dostęp: 12.08.2016).

${ }_{38}$ Zob. http://mahara.org/events (dostęp: 12.08.2016).

39 Zob. http://wiki.mahara.org/index.php/Marketing/Mahara_Presentations; http://wiki.mahara.org/index.php/Marketing/Mahara_Presentations/2014 (dostęp: 12.08.2016).

${ }^{40}$ Por. http://www.foliospaces.org/ (dostęp: 12.08.2016).

${ }^{41}$ https://pol.fronter.com/ (dostęp: 19.08.2016). 


\section{PROPOZYCJA ZASTOSOWANIA EPORTFOLIO W KATECHEZIE MŁODZIEŻY}

Nauczanie papieskie jest cenną inspiracją dla odnowy katechezy, która potrzebna jest także w Polsce. Sugestie takiej odnowy podał Franciszek w przemówieniu do polskich biskupów podczas wizyty Ad limina Apostolorum w 2014 r., powiedział wówczas:

Wiem, że w Polsce uczestniczy w niej [katechezie] większość uczniów w szkołach. Osiągają oni dobrą znajomość prawd wiary. Jednakże religia chrześcijańska nie jest abstrakcyjną wiedzą, ale egzystencjalną znajomością Chrystusa, osobistą relacją z Bogiem, który jest miłością. Być może trzeba położyć większy nacisk na kształtowanie wiary przeżywanej jako relacja, w której doświadcza się radości bycia kochanym i zdolnym do kochania. Trzeba, by wzrastała troska katechetów i duszpasterzy, żeby nowe pokolenia mogły odkryć pełną wartość sakramentów jako uprzywilejowanego miejsca spotkania z żywym Chrystusem i jako źródła łaski ${ }^{42}$.

W zacytowanej wypowiedzi Papież zwrócił uwagę na potrzebę odkrycia w pełni wartości siedmiu sakramentów, zaś w omówionych już przez nas katechezach środowych postulował potrzebę rozbudzenia pamięci chrztu świętego.

Nawiązując do papieskiej sugestii rozbudzenia pamięci chrztu, proponujemy zastosowanie $\mathrm{w}$ szkolnym nauczaniu religii na poziomie szkoły gimnazjalnej metody ePortfolio, ponieważ odpowiada ona potrzebom edukacyjnym nowego pokolenia cyfrowych tubylców. Pozwoli katechizowanym nie tylko przypomnieć sobie datę własnego chrztu św., ale także „zrekonstruować” w szerszym zakresie ten szczególny dzień. Jest to ważne, ponieważ większość uczniów przyjęła zapewne sakrament kilka lub kilkanaście dni po swoich narodzinach i nie może go pamiętać. Coroczna, często uroczysta celebracja dnia urodzin podkreśla wyłącznie aspekt społeczny - przyjście na świat nowego człowieka, w żaden sposób nie nawiązuje do dnia „narodzin dla Kościoła”. Nie celebruje się i nawet $\mathrm{w}$ najprostszej formie nie wspomina tego dnia nawet $\mathrm{w}$ środo-

${ }^{42}$ Słowo Ojca Świętego Franciszka do Konferencji Episkopatu Polski, Ad limina Apostolorum 2014, http://episkopat.pl/slowo-ojca-swietego-franciszka-do-konferencjiepiskopatu-polski-ad-limina-apostolorum-2014/ (dostęp: 16.08.2106). 
wisku eklezjalnym. Dlatego potrzeba ciekawych lekcji religii o chrzcie św., w czasie których katecheci wykorzystując najnowsze możliwości technologii informacyjno-komunikacyjnej (TIK), będą umieli przekonać uczniów, że chrzest to nie tylko jeden dzień z przeszłości, ale wydarzenie stale aktualizujące się w życiu ochrzczonego. Otwiera on drogę do sakramentów św., do których uczniowie przygotowują się na różnych etapach edukacyjnych (szkoła podstawowa - sakrament pokuty i pojednania oraz Eucharystia, gimnazjum - bierzmowanie, szkoły ponadgimnazjalne - sakrament małżeństwa), dlatego trzeba stale podkreślać jego związek $\mathrm{z}$ innymi sakramentami.

Planując wykorzystanie metody ePortfolio w procesie nauczania, należy uwzględnić cele i spodziewane efekty, widziane także z perspektywy ucznia; kontekst edukacyjny; warunki techniczne, między innymi posiadany sprzęt i oprogramowanie, kompetencje techniczne uczniów i nauczyciela, sposób przechowywania i udostępniania ePortfolio ${ }^{43}$. Istotnym kryterium jest wybór liczby uczniów przygotowujących ePortfolio, które może być:

a) indywidualne - każdy uczeń przygotowuje jedno ePortfolio na temat swojego chrztu św. i jego konsekwencji w dalszym życiu;

b) grupowe - może posiadać kilka wariantów:

- katecheta w dowolny sposób dzieli klasę na kilka grup, każda z nich przygotowuje jedno ePortfolio na temat chrztu świętego uczniów wchodzących w skład danej grupy;

- katecheta dzieli uczniów na grupy według miesiąca, w którym przyjęli chrzest święty; w tym przypadku powstaną zespoły o różnej liczbie uczniów, co spowoduje, że grupy najmniej liczebne będą miały najtrudniejsze zadanie;

- katecheta dzieli uczniów na grupy według miejsca (parafii) chrztu świętego, co także spowoduje powstanie zespołów o nierównej liczebności uczniów.

W przypadku tworzenia ePortfolio grupowego należy pamiętać o trudności związanej z obiektywnym ocenieniem zaangażowania poszczególnych uczniów w wykonanie zadania.

${ }^{43}$ Por. http://www.enauczanie.com/eportfolio/metoda/etapy/definiowanie (dostęp: 7.09.2016). 
ePortfolio o chrzcie św. to oryginalna, niepowtarzalna „elektroniczna" wizytówka chrześcijanina. Celem zastosowania ePortfolio w pracy z młodzieżą jest rozbudzenie wśród katechizowanych pamięci chrztu jako dnia narodzin dla Kościoła; pogłębienie refleksji o włączeniu ochrzczonego w Chrystusa i przyłączenia do wspólnoty wiernych; ukazanie aktualizacji chrztu w codziennym życiu; wykonanie elektronicznej „metryki” chrztu. Nie chodzi z pewnością o przygotowanie profesjonalnego ePortfolio, stąd też wybór szaty graficznej itp. należy pozostawić kreatywności uczniów.

Stosując tę metodę, należy pamiętać, że obejmuje ona kilka etapów, które stanowią spójną całość i nie powinny być pomijane:

\subsection{ETAP 1}

Etap I polega na gromadzeniu i selekcjonowaniu elektronicznych artefaktów, którymi mogą być zdjęcia lub krótkie filmy video; skany dokumentów; opisy wydarzeń, umiejętności lub osiągnięć. Ten etap ePortfolio zwany jest niekiedy „roboczym” ${ }^{4}$. W opisywanym przez nas zastosowaniu polega na poszukiwaniu przez uczniów pamiątek z przeszłości, zachowanych przede wszystkim w domowych zbiorach, między innymi: metryki chrztu św., zdjęć oraz filmów z uroczystości w kościele i w domu, pamiątek chrztu św. (okolicznościowych kartek, obrazków św. itp.). W przypadku dokumentów nie będących w formie elektronicznej uczniowie mają dodatkowe zadanie digitalizacji poprzez wykonanie zdjęć lub skanów. Mogę także przeprowadzić i nagrać wywiady lub krótkie filmiki z rodzicami chrzestnymi lub kapłanem, który udzielał im chrztu św. Powinni również odszukać w Internecie (zapisać adresy stron) informacje na temat parafii, w której przyjęli chrzest i diecezji, do której ona należy.

\subsection{ETAP II}

Etap II jest określany jako tzw. ePortfolio refleksyjne, na które składają się: refleksja, autorefleksja, informacja zwrotna (feedback). Zdaniem

${ }^{44}$ Por. http://www.enauczanie.com/eportfolio/metoda/etapy/gromadzenie (dostęp: 7.09.2016). 
L. Hojnackiego „Tak naprawdę to właśnie jest kluczowy element procesu ePortfolio"45, bowiem na tym etapie uczniowie rozwijają i doskonalą swoje umiejętności zarówno refleksji, jak i autorefleksji ${ }^{46}$. Na tym etapie młodzież powinna podjąć refleksję na temat konsekwencji chrztu św. wynikających z włączenia ochrzczonego do wspólnoty eklezjalnej, a więc jego praw i obowiązków w Kościele. Powinna dojść do wniosku, że chrzest otworzył im drogę do Kościoła, umożliwił przyjmowanie innych sakramentów, a przez to zjednoczenie z Chrystusem.

\subsection{ETAP 111}

Etap III to strukturalizacja albo inaczej tzw. ePortfolio strukturalne. Na tym etapie, na podstawie zgromadzonych już artefaktów, uczniowie wyszukują i tworzą zależności pomiędzy poszczególnymi elementami, powiązania, zastosowania. „Etap strukturalizacji łączy w jedną całość nauczanie, uczenie się, ocenianie, rozwój osobisty i profesjonalny. Jest potencjalnie bardzo efektywny i prorozwojowy. Wymaga udostępniania zgromadzonych artefaktów określonym osobom i grupom jako podstawy do dyskusji i pozyskiwania informacji zwrotnej" ${ }^{47}$. Na tym etapie uczniowie powinni poszukiwać zależności między chrztu św. a innymi sakramentami, które już przyjęli (Eucharystia, sakrament pokuty i pojednania) i do których się przygotowują (bierzmowanie). Powinni uzupełnić zgromadzone już dokumenty o materiały związane z Pierwszą Komunią Świętą (zdjęcia, filmiki, pamiątki, itp.) i przygotować je w wersji elektronicznej. Mogą również zaprezentować zgromadzony już materiał nauczycielowi religii w celu dokonania wstępnej oceny i selekcji.

\subsection{ETAP IV}

Etap IV wiąże się z prezentacją, czyli to tzw. ePortfolio prezentacyjne, czyli „kolekcja autentycznych, różnorodnych, wybranych z szerszego

7.09.2016)

${ }^{45} \mathrm{http} / / /$ www.enauczanie.com/eportfolio/metoda/etapy/refleksja (dostęp:

${ }^{46}$ Por. tamże.

${ }^{47}$ http://www.enauczanie.com/eportfolio/metoda/etapy/strukturalizacja (dostęp: 7.09.2016) 
zbioru dowodów i przykładów, reprezentujących to, czego właściciel (tu: uczeń) nauczył się w przeciągu dłuższego czasu, czego jest świadom i co wybrał do zaprezentowania konkretnemu odbiorcy lub szerszej grupie odbiorców w określonym celu i w konkretnym zastosowaniu" ${ }^{48}$. Ostatnim etapem przygotowania ePortfolio o chrzcie św. jest jego prezentacja i ocena. Oceniając pracę uczniów, katecheta powinien uwzględnić takie elementy jak: zawartość merytoryczną ePortfolio, sposób wykonania zadania i prezentacji, a w przypadku ePortfolio grupowego - współpracę w zespole.

Mając na uwadze powyższe etapy, nauczyciel religii pracujący z młodzieżą gimnazjalną, musi dokonać wyboru czasu, w którym uczniowie będą przygotowywali swoje ePortfolia. Krótki termin (np. miesiąc) może być dla uczniów zbyt dużym obciążeniem, dlatego należy zaplanować dłuższy okres:

a) jeden rok szkolny - np. tylko III klasa gimnazjum, wówczas prezentacja ePortfolio może odbyć się na zakończenie szkolnego etapu przygotowania do bierzmowania;

b) jeden etap edukacyjny, czyli klasy I-III gimnazjum, wówczas prezentacja ePortfolio może odbyć się w ostatniej klasie i być połączona $\mathrm{z}$ bezpośrednim przygotowaniem do bierzmowania;

c) dwa etapy edukacyjne - gimnazjum i szkoła ponadgimnazjalna, wówczas prezentacja ePortfolio może odbyć się w klasie maturalnej pod warunkiem, że nauczyciel religii pracujący $\mathrm{w}$ gimnazjum mam kontakt $\mathrm{z}$ katechetami uczącymi w szkołach ponadgimnazjalnych. Ten rodzaj pracy z ePortfolio możliwy jest do zastosowania przede wszystkim $\mathrm{w}$ małych środowiskach.

Prezentacja ePortfolio może odbyć się w klasie lub za zgodą autorów udostępniona także w Internecie, stając się w ten sposób wizytówką chrześcijanina w Sieci.

${ }^{48}$ http://www.enauczanie.com/eportfolio/metoda/etapy/prezentacja (dostęp: 


\section{ZAKOŃCZENIE}

Obowiązujący obecnie Program nauczania religii (2010 r.) dla gimnazjum proponuje tylko jedno zagadnienie "Chrzest jako pascha chrześcijanina i sakrament wolności dzieci Bożych” (s. 120). Pojedyncza lekcja o paschalnym wymiarze chrztu to bez wątpienia za mało. Uczniowie często nie tylko nie pamiętają daty swojego chrztu świętego, lecz także nie rozumieją eklezjalnych skutków włączenia do Kościoła, braterskiej wspólnoty uczniów Chrystusa. Nie chcą angażować się w życie parafii, ponieważ mają błędne wyobrażenie, widząc w niej tylko instytucję zajmującą się „dystrybucją” usług religijnych. Dlatego przygotowanie młodzieży gimnazjalnej do sakramentu bierzmowania powinno uwzględniać pogłębioną refleksję o chrzcie świętym i jego eklezjalnych skutkach. Należy przywrócić pamięć chrztu świętego, w czym bez wątpienia pomocne może być ePortfolio. Jest ono cyfrowym narzędziem zastępującym papierowy zeszyt, w którym można systematycznie zapisywać i dokumentować własny proces uczenia się. W omówionym przez nas zastosowaniu, ePortfolio powinno służyć jako narzędzie dokumentowania duchowego wzrastania we wspólnocie Kościoła. W takim zakresie jest to nowatorski sposób wspierania procesu katechetycznego związanego z przygotowywaniem młodzieży do sakramentu dojrzałości chrześcijańskiej.

Streszczenie. Obchody 1050 rocznicy chrztu Polski, przypadające w 2016 roku, kierują uwagę nie tylko w stronę wydarzenia, które przed wiekami radykalnie wpłynęło na losy polskiego narodu i Kościoła, ale także na sakrament chrztu świętego - wydarzenie całkowicie zmieniające duchowe życie ochrzczonego. Okres niemowlęctwa, w którym najczęściej w Polsce przyjmuje się chrzest powoduje, że często zapomina się o tym dniu, nie pamięta jego daty. Dlatego potrzeba działań duszpasterskich i katechetycznych mających na celu rozbudzenie wśród wiernych pamięć dnia zrodzenia do życia nadprzyrodzonego. Celem artykułu Rozbudzić pamięć chrztu. Katecheza o chrzcie św. z wykorzystaniem ePortfolio dr hab. Beaty Bilickiej jest opisanie zastosowania metody ePortfolio w szkolnym nauczaniu religii, w celu rozbudzenia pamięci chrztu, o którą nieraz prosił papież Franciszek. Artykuł dzieli się na trzy części. W pierwszej krótko scharakteryzowane zostały istotne elementy papieskiej katechezy o chrzcie świętym. Następnie przedstawiono narzędzia niezbędne do tworzenia ePortfolio. W przedostatnim punkcie opisano zastosowanie metody ePortfolio w szkolnym nauczaniu religii, w celu rozbudzenia pamięci chrztu wśród młodzieży gimnazjalne. Artykuł wieńczy krótkie zakończenie. Podstawowym źródłem opracowania są przede wszystkim dwie katechezy środowe na 
temat chrztu świętego, wygłoszone przez papieża Franciszka w cyklu siedmiu katechez o sakramentach.

Słowa kluczowe: chrzest święty; nauczanie papieża Franciszka; ePortfolio; nauczanie religii.

Abstract. Awakening the Memory of our Baptism. (Catechesis on the Holy Baptism Using an ePortfolio). The celebrations of the 1050th anniversary of Poland's Baptism, which fall in 2016, direct our attention not only to the event which ages ago radically influenced the history of the Polish nation and the Church but also to the sacrament of baptism, an event which transforms the spiritual life of the baptised. In Poland a period of infancy is the preferred time for baptism and thus many people forget this day and do not remember its date. Therefore there is a need for pastoral and catechetical action among the faithful to awaken the memory of the day of being born to a new supernatural life. The aim of the article entitled Awakening the Memory of our Baptism. Catechesis on the Holy Baptism Using an ePortfolio by Professor Beata Bilicka is to present the use of the ePortfolio method in teaching Religious Education in order to awaken the memory of baptism, which has been repeatedly pleaded for by Pope Francis. The article is divided into three parts. In the first part, the most essential elements of the Pope's Catechesis on baptism have been characterised. It is followed by the presentation of tools which are necessary to create ePortfolio. Next, there is a description of application of the ePortfolio method to teaching Religious Education in order to awaken the memory of baptism among students of the lower-secondary schools. The article ends with a short conclusion. The basic source for this article is two of the General Audience Catecheses concerning baptism by Pope Francis which form a series of seven catecheses on the sacraments.

Keywords: Holy Baptism; the teaching of Pope Francis; ePortfolio; Religious Education teaching.

\section{BIBLIOGRAFIA}

Bilicka B., ePortfolio $i$ WebQuest $w$ szkolnym nauczaniu religii, w: Katecheta $i$ katechizowany $w$ Sieci, red. taż, Toruń 2015, s. 87-111.

Franciszek, Ad limina Apostolorum 2014, http://episkopat.pl/slowo-ojca-swietegoranciszka-do-konferencji-episkopatu-polski-ad-limina-apostolorum-2014/ (dostęp: 16.08.2106).

Franciszek, Chrzest czyni członkami Kościoła. Katecheza papieża Franciszka z 15 stycznia 2014 r., http://papiez.wiara.pl/doc/1851823.Chrzest-czyni-czlonkami-Ciala-i-Ludu (dostęp: 16.08.2106).

Franciszek, Chrzest na odpuszczenie grzechów. Katecheza papieża Franciszka z 13 listopada 
2013 r., http://papiez.wiara.pl/doc/1777993.Chrzest-na-odpuszczenie-grzechow (dostęp: 16.08.2106).

Franciszek, To jest dzień święta. Katecheza papieża Franciszka $z 8$ stycznia 2014 r., http://papiez.wiara.pl/doc/1841479.To-jest-dzien-swieta (dostęp: 16.08.2106).

http://electronicportfolios.org/ (dostęp: 25.07.2016).

http://mahara.org/ (dostęp: 12.08.2016).

http://mahara.org/events (dostęp: 12.08.2016).

http://sites.google.com (dostęp: 12.08.2016).

http://wiki.mahara.org/index.php/Marketing/Mahara_Presentations/2014 (dostęp: 12.08.2016).

http://wiki.mahara.org/index.php/Marketing/Mahara_Presentations;

http://wikieducator.org/Mahara_i_ePortfolio_-_samouczek (dostęp: 12.08.2016). http:// wiki.mahara.org/index.php/System_Administrator\%27s_Guide/Installing_Mahara (dostęp: 12.08.2016).

http://www.enauczanie.com/eportfolio (dostęp: 12.08.2016).

http://www.enauczanie.com/eportfolio/metoda (dostęp: 12.08.2016).

http://www.enauczanie.com/eportfolio/metoda/etapy (dostęp: 12.08.2016).

http://www.enauczanie.com/eportfolio/metoda/etapy/definiowanie (dostęp: 7.09.2016).

http://www.enauczanie.com/eportfolio/metoda/etapy/gromadzenie (dostęp: 7.09.2016).

http://www.enauczanie.com/eportfolio/metoda/etapy/prezentacja (dostęp: 7.09.2016).

http://www.enauczanie.com/eportfolio/metoda/etapy/refleksja (dostęp: 7.09.2016).

http://www.enauczanie.com/eportfolio/metoda/etapy/strukturalizacja (dostęp: 7.09.2016).

http://www.enauczanie.com/eportfolio/narzedzia/blogi (dostęp: 12.08.2016).

http://www.enauczanie.com/eportfolio/narzedzia/google-sites (dostęp: 12.08.2016).

http://www.enauczanie.com/eportfolio/narzedzia/mahara (dostęp: 12.08.2016).

http://www.enauczanie.com/eportfolio/narzedzia/prezentacje (dostęp: 12.08.2016).

http://www.enauczanie.com/eportfolio/narzedzia/statyczne (dostęp: 12.08.2016).

http://www.enauczanie.com/eportfolio/podrecznik (dostęp: 25.07.2016).

http://www.enauczanie.com/start (dostęp: 25.07.2016).

http://www.foliospaces.org/ (dostęp: 12.08.2016).

http://www.theijep.com/ (dostęp: 25.07.2016).

https://pol.fronter.com/ (dostęp: 19.08.2016).

Osial W., Wizja wspótczesnej katechezy w nauczaniu papieża Franciszka, „Warszawskie Studia Teologiczne" 27 (2014) 1, s. 293-306.

Semeraro M., Wprowadzenie do adhortacji apostolskiej „Evangelii gaudium”, tłum. K. Stopa, Częstochowa 2014, s. 7-17. 